\title{
PENGGUNAAN BITCOIN SEBAGAI ALAT PEMBAYARAN ZAKAT MENURUT PERSPEKTIF HUKUM ISLAM
}

\author{
1Rahmadi Indra Tektona, ${ }^{2}$ Nadya Ulfa Safilia \\ ${ }^{12}$ Hukum Bisnis Syariah,Fakultas Hukum, Universitas Jember \\ E-mail: 1rahmadiindra@unej.ac.id, 2nadyasafilia@gmail.com
}

\begin{abstract}
Zakat payments are increasingly developing in the current digital era, the Shackwell Lane Mosque in Hackney, London, England accepts zakat payments in other forms other than cash which is of cryptocurrencies such as Bitcoin. Related to the halal controversy and the prohibition of the use of bitcoin digital currency in Islamic law, Zayd al-Khair as a religious adviser at the mosque said, if Islamic scholars have argued and supported the use of cryptocurrencies. The purpose of this study is to find out and understand the use of bitcoin as a purpose of payment of zakat that is legal and accordance with Islamic law or not, in the sense that nothing deviates from the principles of Islamic law. The research method used is normative juridical. Bitcoin can be said to be haram because it contains the element of gharar and cannot be used as zakat payment. This is reinforced by the MUI fatwa No. 13 of 2011 about the law of zakat on haram assets which emphasizes that haram assets cannot be the compulsory object of zakat.
\end{abstract}

\section{Keywords:}

zakat payment, bitcoin, Islamic law

\begin{abstract}
Abstrak
Pembayaran zakat semakin berkembang di era digital saat ini, Masjid Shackwell Lane di Hackney, London, Inggris menerima pembayaran zakat dalam bentuk lain di luar uang tunai yaitu berupa mata uang kripto seperti Bitcoin. Terkait dengan kontroversi halal dan haramnya penggunaan mata uang digital bitcoin dalam hukum Islam, Zayd al-Khair sebagai penasihat agama di masjid mengatakan, jika para cendekiawan Islam telah berdebat dan mendukung penggunaan mata uang kripto. Tujuan penelitian ini yaitu untuk mengetahui dan memahami penggunaan bitcoin sebagai alat pembayaran zakat yang sah dan sesuai dengan hukum Islam atau tidak, dalam arti tidak ada hal-hal yang menyimpang dari prinsip hukum Islam itu sendiri. Metode penelitian yang digunakan yaitu tipe penelitian yuridis normatif. Bitcoin dapat dikatakan haram karena mengandung unsur gharar dan tidak dapat digunakan sebagai pembayaran zakat. Ini diperkuat dengan Fatwa MUI No 13 Tahun 2011
\end{abstract}


tentang Hukum Zakat atas Harta Haram yang menegaskan bahwa harta haram tidak bisa menjadi objek wajib zakat.

\section{Kata-kata Kunci:}

pembayaran zakat, bitcoin, hukum Islam

\section{Pendahuluan}

Islam merupakan agama universal yang tidak pernah lekang oleh zaman untuk mengatur akidah, syariah, serta akhlak secara komprehensif. Pada dasarnya Islam mengandung ajaran yang bersifat absolut terutama dalam ilmu pengetahuan dan teknologi. Islam sangat mementingkan ilmu pengetahuan dan teknologi dalam kehidupan manusia karena martabat manusia tidak hanya ditentukan oleh aqidah dan akhlaknya namun juga ditentukan dalam kemampuan mengembangkan ilmu pengetahuan. Lahirnya Islam membawa manusia kepada sumber pengetahuan baru, memperkenalkan aturan baru yang mencakup kehidupan material seperti pendidikan, politik, kebudayaan, serta ekonomi. Dewasa ini, kegiatan ekonomi dari waktu ke waktu banyak mengalami perubahan, jika yang dulunya tidak ada sekarang ada dan sebaliknya. Sebelumnya uang diciptakan sebagai alat transaksi manusia mengunakan sistem barter dalam berdagang. Perekonomian sistem barter adalah suatu sistem jalannya perekonomian yang mana sistem transaksi barangnya di pertukarkan dengan barang. Pada dasarnya Setiap barang berfungsi sebagai uang. ${ }^{1}$

Ketika para pelaku ekonomi telah menemukan uang sebagai alat transaksi, kemudian waktu demi waktu telah berlalu disepakatilah secara bersama uang sebagai alat tukar dalam perekonomian. Peranan uang bertambah selaras dengan bertambah fungsinya, uang tidak lagi sekedar sebagai alat pertukaran tetapi berfungsi sebagai satuan hitung atau pengukur nilai (units of account), alat penimbun kekayaan (store of value), dan standar pembayaran tundaan (standard of defferred payments), dan bahkan pada masa sekarang uang bisa berfungsi sebagai barang komoditi. ${ }^{2}$ Dalam berkembangnya perekonomian saat ini, lalu lintas pertukaan barang dan jasa sudah semakin pesat dan cepat, sehingga memerlukan sistem pembayaran yang cepat, efisien, dan aman.

\footnotetext{
${ }^{1}$ Sandra Wijaya, Skripsi: Transaksi Jual Beli Bitcoin Dalam Perspektif Hukum Islam, (Yogyakarta: Universitas Islam Indonesia, 2018), hlm. 2

2 Indra Darmawan, Pengantar Uang dan Perbankan (Jakarta:PT Rineka Cipta, 1992), hlm. 13
} 
Pengaruh yang sangat kuat yang dimunculkan oleh kemajuan teknologi pada semua aspek kehidupan tak terkecuali dalam sistem pembayaran. Sistem pembayaran pun berubah sepanjang waktunya dengan melihat evolusi sistem pembayaran dalam perekonomian. Bentuk uang pun terus berubah seiring perkembangan waktu, diawali dengan sistem pembayaran dengan menggunakan logam berharga seperti emas dan perak, lalu berubah menjadi aset kertas seperti cek dan uang kertas. Perkembangan sistem pembayaran yang berbasis teknologi telah mengubah secara signifikan arsitektur sistem pembayaran konvensional yang mengandalkan fisik uang sebagai instrumen pembayaran. Meski fisik uang sampai saat ini masih banyak digunakan masyarakat dunia sebagai alat pembayaran, namun sejalan dengan perkembangan teknologi sistem pembayaran yang pesat, pola pembayaran tunai (cash) secara berangsur beralih menuju pembayaran non tunai (non-cash). ${ }^{3}$

Akan tetapi sistem mata uang fiat yang sekarang ini digunakan sebagai transaksi online masih terbatas aturan regulasi suatu negara yang memiliki keterbatasan dalam hal privasi, biaya transaksi, inflasi, dan sebagainya. Dari segala keterbatasan inilah muncul suatu ide dari beberapa orang untuk menciptakan suatu jenis mata uang baru yang diharapkan dapat mengatasi permasalahan dimasyarakat dalam bertransaksi tanpa adanya campur tangan pihak ketiga terhadap privasinya. Ide penciptaan mata uang tersebut mulai muncul yang berbasiskan pada Cryprography. ${ }^{4}$ Penggunaan lain dari Cryprography yang dapat menunjang kehidupan masyarakat dalam jual beli mata uang digital disebut dengan Cryptocurrency. Cryptocurrency merupakan mata uang digital dengan konsep kriptografi atau kode rahasia sebagai sistem keamanannya. Bitcoin sebagai bentuk cryptocurrency pertama yang muncul, telah berkembang di tengah keberadaan sistem keuangan konvesional yang digunakan sebagai alat pembayaran layaknya mata uang pada umumnya. ${ }^{5}$ Bitcoin merupakan jaringan konsensus yang memungkinkan sistem pembayaran baru dan uang yang sepenuhnya berbentuk digital. Bitcoin merupakan jaringan

${ }^{3}$ R. Maulana Ibrahim, Paper Seminar Internasional Toward a Less Cash Society in Indonesia (Jakarta: Direktorat Akunting dan Sistem Pembayaran Bank Indonesia, 2006), hlm. 12

4 Dimaz A. Wijaya, Mengenal Bitcoin \& Cryptocurrency, (Medan: Puspantara, 2016), hlm.10

${ }^{5}$ Dimas Ankaa Wijaya dan Oscar Darmawan, Blockchain dari Bitcoin untuk Dunia, (Jakarta: Jasakom, 2017), hlm. 8 
pembayaran peer-to-peer desentralisasi pertama yang dikontrol sepenuhnya oleh penggunanya tanpa ada otoritas sentral ataupun perantara. ${ }^{6}$

Namun keberadaan Bitcoin sebagai pengganti mata uang atau alat pembayaran di beberapa negara masih terjadi pro kontra. Di Indonesia sendiri Bitcoin belum memenuhi syarat sebagai mata uang seperti yang tercantum dalam Undang-Undang Nomor 7 Tahun 2017 tentang mata uang pasal 1 ayat 1 disebutkan bahwa " mata uang adalah uang yang dikeluarkan oleh Negara Kesatuan Republik Indonesia yang selanjutnya disebut Rupiah". Bitcoin tidak hanya digunakan dalam ranah bisnis online, namun nyatanya juga hadir dan dipergunakan dalam kehidupan masyarakat dunia terutama yang beragama Islam. Penggunaan Bitcoin juga dapat digunakan sebagai pembayaran zakat. ${ }^{7}$

Ditengah pro kontra karena keberadaan Bitcoin terdapat beberapa oknum yang memfasilitasi pembayaran zakat menggunakan uang virtual atau Bitcoin. Membayar zakat merupakan salah satu prinsip utama umat Islam. Dalam rukun Islam, membayar zakat menempati urutan ketiga setelah mengucapkan syahadat dan melaksanakan shalat. Zakat adalah ibadah yang bertalian dengan harta benda. Persoalan masjid Shackwell Lane di Hackney di London yang menerima pembayaran zakat dengan uang kripto menimbulkan kekhawatiran terkait kehalalannya. konsepsi mata uang bitcoin sebagai alat transaksi pembayaran terutama dalam pembayaran zakat mengalami perdebatan dikalangan ahli dari segi manfaat dan kemudharatannya. Berdasarkan Latar Belakang di atas, rumusan masalah dalam Penelitian ini adalah Bagaimana pandangan hukum Islam terhadap bitcoin sebagai alat pembayaran zakat. Tujuan Penelitian untuk mengetahui dan memahami penggunaan bitcoin sebagai alat pembayaran zakat yang sah dan sesuai dengan hukum Islam atau tidak, dalam arti tidak ada hal-hal yang menyimpang dari prinsip hukum Islam itu sendiri. Metode penelitian yang digunakan yaitu tipe penelitian yuridis normatif (legal research). Penelitian menggunakan pendekatan konseptual (Conteptual Aprouch). Bahan hukum yang digunakan dalam penelitian ini yaitu bahan hukum sekunder yang diperoleh dari buku-buku teks/literature hukum, jurnaljurnal hukum, serta sumber tertulis lainnya, dan bahan non hukum yang diperoleh dari internet, kamus ataupun karya ilmiah lainnya.

${ }^{6}$ https://bitcoin.org/id/faq (diakses tanggal 27-03-2019)

https://www.cnnindonesia.com/teknologi/20180524143721-185-300968/ masjid-di-inggris-halalkan-bitcoin-untuk-bayar-zakat (Diakses tanggal 18-07-2019) 


\section{Hasil dan Pembahasan}

\section{Bitcoin Sebagai Alat Pembayaran Zakat}

Bitcoin merupakan salah satu bentuk mata uang yang diakui para penggunanya, sebagai salah satu bentuk mata uang digital seperti bitcoin sudah tidak asing lagi dalam dunia transaksi keuangan online . Kini, bitcoin telah menjadi salah satu alat transaksi pembayaran yang cukup praktis dan efisien di kalangan komunitas pebisnis (merchant) atau pengguna itu sendiri. Dengan keefesiennya maka Bitcoin menjadi salah satu cryptocurrency yang semakin hari semakin terkenal dan banyak yang berminat untuk menggunakannya. Pilihan terhadap bitcoin yang digunakan sebagai bentuk alat pembayaran transaksi keuangan online, membuat para ahli ekonomi terutama ahli fiqih Islam mengkaji lebih serius dan mendalam. Dikarenakan bitcoin berbeda dengan mata uang sebelumnya yaitu yang diakui dalam Islam setelah dinar (emas), dirham (perak) adalah mata uang kertas (fiat money) sebagai salah satu bentuk mata uang yang diakui saat ini. Sampai sekarang pun bitcoin sendiri masih menjadi polemik yang sangat panjang dan bahkan menjadi perdebatan di kalangan para ulama yang masih mempertahankan argumen klasiknya.

Perkembangan transaksi yang menggunakan bitcoin menimbulkan dampak atau implikasi terhadap penggunanya, dikarenakan bitcoin memberikan ruang segar sehingga tidak dapat dihindarkan bahwa transaksi yang menggunakan jenis uang virtual ini memiliki keuntungan yang cukup menggiurkan dan juga memberikan kemudahan bagi pelaku usaha (merchant) dan para pengguna atau komunitas yang menggunakan bitcoin sebagai alat pembayaran transaksi mereka. Akan tetapi terdapat juga dampak yang akan dihadapi khususnya bagi pengguna atau komunitas bitcoin itu sendiri. Bahwa di sisi keamanannya sendiri tidak bisa dipertanggungjawabkan, seperti yang diketahui bahwa bitcoin dalam sisi legalitasnya merupakan salah satu bentuk mata uang yang tidak diakui sebagai mata uang di beberapa negara termasuk di Indonesia. ${ }^{8}$

Bitcoin diciptakan oleh Satoshi Nakamoto pada tahun 2009. Nama Satoshi Nakomoto ini merupakan nama samaran sang pencipta bitcoin ini. Konsep dari bitcoin sendiri jauh berbeda dengan mata uang pada umumnya (fiat currency). Bitcoin merupakan salah satu bentuk produk digital yang hanya diperjualbelikan melalui internet dan tidak terdapat bentuk fisik,

${ }^{8}$ Luqman Nurhisam, Bitcoin Dalam Kacamata Hukum Islam, Vol. 4, No. 1, Juni 2017, hlm. 173 
seperti uang kertas maupun uang logam. Menurut Nakamoto, sebagai sistem pembayaran daring antara penjual dengan pembeli bitcoin dirancang untuk bertransaksi secara langsung tanpa melibatkan pihak ketiga sehingga lebih efesien. Proses transaksinya menggunakan tanda tangan rahasia yang disebut kriptografi yang berfungsi untuk pengamanan sehingga tidak akan terjadi pemalsuan dan pengeluaran ganda.

Transaksi keluar masuknya Bitcoin akan dicatat dan disebarkan secara terbuka, diverifikasi melalui jaringan komputer menggunakan kriptografi, dihubungkan secara peer-to-peer, dan didistribusikan pada seluruh jaringan luas komputer pemilik bitcoin di seluruh dunia. Bitcoin tidak disimpan pada akun seperti di bank yang sewaktu-waktu dapat dibekukan, akan tetapi disimpan pada dompet komputer atau disebut file wallet sehingga dapat dikontrol setiap saat. Penggunaan bitcoin dalam transaksi pun tidak ada pembatasan sebagaimana transaksi di bank. Jumlah bitcoin tidak banyak karena Satoshi hanya mendesain algoritma untuk 21 juta bitcoin. Transaksi dengan menggunakan bitcoin di dunia maya ini menggunakan tanda tangan rahasia berupa rangkaian simbol yang disebut kriptografi.

Kriptografi bekerja atas dasar enskripsi algoritma yang dibuat secara khusus dan digunakan untuk memvalidasi dan memverifikasi transaksi yang terjadi. Transaksi menggunakan bitcoin tidak menyertakan nama sehingga pemilik tidak dapat diidentifikasi. Semua transaksi bitcoin kemudian disebar ke seluruh jaringan komputer pengguna bitcoin seluruh dunia. bitcoin tidak akan terkena inflasi dan tidak terpengaruh oleh pergantian pemerintahan. Uang digital bitcoin dapat dianggap sebagai barang komoditas sebagaimana emas. Fluktuasi nilai tukar bitcoin bergantung pada permintaan pengguna atau investor serta sangat dipengaruhi oleh penerimaan atau penolakan negara.

Di samping banyak keunggulannya, bitcoin juga memiliki sejumlah kelemahan antara lain tidak adanya nilai intrinsik, tidak memiliki aset yang mendasari (underlaying asset), tidak ada lembaga otoritas yang menaungi dan bertanggung jawab, tidak terdapat nama jelas pemiliknya sehingga tidak aman dan rawan terjadi tindak kejahatan seperti pencucian uang dan penipuan. Naik turunnya nilai bitcoin berdasarkan hukum kebutuhan pasar dan penawaran. Ketika bitcoin yang beredar hanya sedikit untuk memenuhi kebutuhan sedangkan permintaan banyak, jumlah bitcoin yang tersisa harganya akan naik. Dengan demikian, transaksi bitcoin termasuk dalam gambling transaction. Bitcoin memiliki "risiko konvertibilitas" yakni tidak 
ada jaminan dapat ditukarkan dengan uang fiat konvensional apalagi dengan volatilitas harga tinggi. ${ }^{9}$

Landasan dalam Al-Quran Ada dua ayat yang dijadikan landasan pembahasan hukum penggunaan bitcoin, baik sebagai instrumen investasi maupun sebagai instrumen transaksi bisnis, yaitu dalam surat An-Nisa (4) ayat 29:

"Wahai orang-orang beriman, janganlah kamu saling memakan harta sesamamu dengan jalan yang batil, kecuali dalam perdagangan yang berlaku atas dasar suka sama suka di antara kamu. Dan janganlah kamu membunuh dirimu. Sungguh Allah Maha Penyayang kepadamu"

Dan surat al-Maidah [5] ayat 90 Allah SWT berfirman:

"Wahai orang-orang yang beriman! Sesungguhnya minuman keras, maysir (judi), (berkurban) untuk berhala, dan mengundi nasib dengan anak panah adalah perbuatan keji dan termasuk perbuatan setan. Maka jauhilah (perbuatan-perbuatan) itu agar kamu beruntung".

Dari kedua ayat tersebut terdapat dua kata kunci yang dapat ditafsirkan, yaitu kata batil dan maysir.

Kajian tafsir tentang batil yaitu menurut Imam Al-Ashfahani di dalam kitab Al-Mufradat fi Garib al-Quran halaman 56 menjelaskan kata batil berasal dari bathala - yabthulu 'rusak', 'palsu', atau 'tidak sah'. Adapun secara istilah, batil adalah al-batil naqidlun al-haqqi wa hua ma la tsabata lahu 'inda al-fahsyi 'anhu. Batil merupakan kebalikan dari kebenaran, yaitu hal yang tidak tetap ketika diteliti. Dan menurut Al-Shabuni di dalam kitab Shafwah al-Tafasir halaman 271 menerangkan albatili hua kullu thariqin lam tabhahu al-syariatu ka al-sirqati wa al-khiyanah wa al-ghasab wa al-riba wa al-qimar wama syakilun dzalika, batil adalah setiap jalan yang tidak dibolehkan oleh syara', seperti mencuri, khianat, korupsi, riba, judi, dan halhal yang sejenis dengan itu.

Kajian tafsir tentang maysir menurut Muhammad Quresh Shihab di dalam tafsir Al-Misbah jilid 3 halaman 236 menyatakan, maysir berasal dari kata yusr yang berarti mudah. Seseorang yang berjudi, mudah memperoleh

${ }^{9}$ Asep Zaenal Ausop \& Elsa Silvia Nur Aulia, Teknologi Cryptocurrency Bitcoin Untuk Investasi Dan Transaksi Bisnis Menurut Syariat Islam, Jurnal Sosioteknologi, Vol. 17, No 1, April 2018, hlm. 80 DOI: http://dx.doi.org/10.5614\%2Fsostek.itbj.2018.17.1.8 
harta tapi mudah pula kehilangan hartanya. Begitupula menurut Al-Shabuni di dalam kitab Tanwir al-Adzhan min tafsir Ruh al-Bayan Jilid I halaman 442 menjelaskan, almaysir ae alqimar kulluhu fayadkhulu fihi al-Nardu wa alsyithranji wa ghairu dzalika mimma yuqamiruna bih. Maysir adalah segala bentuk perjudian termasuk di dalamnya bermain dadu dan catur yang biasa digunakan untuk bertaruh. Pada hakikatnya maysir termasuk gharar karena ada unsur ketidakjelasan dan bersifat untung-untungan atau spekulasi tinggi/gambling. ${ }^{10}$

Penerapan hukum untuk kasus bitcoin diumpamakan dengan kasus menjual ikan dalam air, yaitu pertama, Al-ashl-nya adalah menjual beli ikan dalam air; kedua, Furu'-nya adalah menjual beli uang virtual bitcoin di dunia maya; ketiga, Hukum ashal-nya adalah haram menjual beli ikan di dalam air; keempat, 'illat atau kesamaan sifatnya, yaitu sama-sama membeli sesuatu yang tidak jelas, baik kuantitas maupun kualitas barangnya. Dengan demikian, melakukan jual beli bitcoin sama dengan jual beli ikan di dalam air, yakni sama-sama mengandung unsur gharar (tidak jelas).

Pengunaan bitcoin pada dasarnya hukumnya mubah, hal ini sesuai dengan kaidah "Asal segala sesuatu itu adalah mubah, hingga ada dalil yang menunjukkan keharamannya." Akan tetapi, jika dilihat kepada kasus-kasus yang pernah terjadi pada pemanfaatannya, penggunaan bitcoin menghasilkan suatu efek perbuatan yang jika merujuk kepada pembagian efek perbuatan dalam maqâșid al-syarīiyah dikategorikan kepada efek perbuatan yang menimbulkan mudarat kepada orang lain dan dilakukan dengan sengaja, karena pada umumnya seseorang yang ingin menggunakan bitcoin, terlebih dahulu akan mencari tahu tentang bitcoin sebelum menggunakannya, maka dapat dikatakan bahwa mereka sengaja menggunakan bitcoin walaupun telah mengetahui efek negatif yang ditimbulkan pada penggunaan bitcoin. Namun, yang ingin menggunakan bitcoin ini hanya menginginkan kemudahan dan keuntungan yang mendasari niat dasar pada penggunaannya, mereka tidak bermaksud untuk menimbulkan mudarat kepada orang lain. Walaupun mereka tidak bermaksud untuk menimbulkan mafsadat kepada orang lain, akan tetapi efek mudarat yang dihasilkan bersifat pasti, artinya efek mudaratnya dapat dipastikan dan nilai mafsadatnya ini lebih besar jika dibandingkan dengan nilai maslahat.

${ }^{10}$ Ibid., hlm. 83 
Nilai mafsadat yang dihasilkan pada penggunaan bitcoin masuk ke hâjjiyyâat dan bisa naik ke tingkat ḍarûriyyât, karena bitcoin bernilai harta. Oleh karena itu, harta yang merupakan salah satu unsur dari lima unsur maqâșid al-syar'ìyah yang menjadi tujuan syariat harus dijaga dan dipelihara karena harta termasuk kepada tingkat ḍarûriyyât yang apabila tidak dijaga akan menimbulkan kesempitan dan kerusakan. Tanpa adanya harta, perkara-perkara duniawi dan agama seseorang tidak bisa terlaksana dengan baik. Penggunaan bitcoin menimbulkan tingkat mafsadat yang ditimbulkan oleh lebih besar dibandingkan tingkat maslahat yang dihasilkan. Tingkat kemaslahatan penggunaan bitcoin berada pada tingkat hâjjiyyâat, sedangkan tingkat mafsadatnya jauh lebih besar dari hâajiyyâat, yaitu berada pada tingkat darûriyyât. Maka penggunaan bitcoin jika dikaji dari segi Maqasid Al-Syariah merupakan sesuatu yang harus dihindarkan, karena menolak mafsadat lebih diutamakan dari pada mewujudkan kemaslahatan. hal ini sesuai dengan kaidah "Menolak kerusakan lebih utama dari mewujudkan maslahat." ${ }^{11}$

Mengenai konsep bitcoin dan mata uang virtual lainnya sebagai bentuk mata uang sendiri masih banyak menjadi pro-kontra dikalangan para ahli dan para ulama islam yang masih dikaji lebih lanjut, karena bitcoin dan mata uang virtual lainnya sebagai alat pembayaran masih perlu banyak pertimbangan baik dari segi manfaat dan madharatnya. Bahsul Masail PWNU Jatim berpendapat, berdasarkan Hasil Keputusan Bahtsul Masail PWNU Jawa Timur tanggal 10-11 Februari 2018 di Tuban, bitcoin dikelompokkan sebagai "harta virtual" sehingga boleh dijadikan sebagai alat transaksi dan dapat dijadikan sebagai investasi. Sehingga dengan demikian berlaku wajib zakat dengannya. ${ }^{12}$

Berdasarkan rujukan di atas bitcoin dapat diartikan serupa dengan duyun atau dain yang secara harfiyyah memiliki makna piutang. Menurut perspektif fiqh muamalah didefinisakan sebagai harta yang berada dalam tanggung jawab, maksudnya adalah harta yang masih dalam bentuk hutang-piutang yang harus diselesaikan yang merupakan harta pemberi hutang yang masih dalam tanggung jawab penghutang. Harta dain dalam perspektif fiqh muamalah digolongkan dalam klasifikasi pembagian harta

${ }^{11}$ Dara Lidia, Eksistensi Bitcoin Dalam Perspektif MaqāṢid Al-Syar'İyah, Petita, Volume 3, Nomor 2, Januari-Juni 2018, hlm. 165

https://islam.nu.or.id/post/read/86225/hukum-transaksi-dengan-bitcoin (Diakses tanggal 29-01-2020) 
bersama harta ain (harta yang berwujud atau berbentuk benda seperti rumah, kendaraan dan sebagainya). Oleh karena itu dapat dipahami dengan mafhum mukhalafah bahwa harta dain adalah harta yang tidak berwujud (aset yang tidak berwujud /financial asset) kebalikan dari harta ain yang dipahami sebagai harta berwujud. Hal ini dikarenakan harta di substansikan sebagai segala hal yang memiliki nilai, dapat dikuasai, bermanfaat dan tabiat manusia condong kepadanya.

Terkait penggolongan bitcoin sebagai harta virtual, maka status bitcoin menjadi lebih umum jika dibandingkan dengan penggunaan frase mata uang virtual. Karena keduanya memiliki implikasi hukum yang berbeda, yang mana keumuman dari suatu harta yaitu mencakup mata uang dan harta-harta lainnya seperti emas perak dan sesuatu yang dianggap bernilai, sedangkan mata uang merupakan bagian dari harta. Jadi sederhananya mata uang adalah harta, namun harta tidak hanya mata uang atau belum tentu mata uang bisa berupa selain mata uang. ${ }^{13}$

Para ulama kontemporer mendefinisikan harta yaitu dengan segala sesuatu yang dapat menjadi hak milik seseorang dan dapat diambil manfaatnya. Bahkan Imam Syafi'i menganggap segala sesuatu yang memiliki nilai uang atau materi dikalangan masyarakat adalah harta. Dari definisi diatas maka segala sesuatu berupa benda maupun tidak, baik berupa nyata maupun yang abstrak merupakan pengertian harta. Para mubahitsin mengangap bahwa bitcoin digolongkan sebagai harta karena harta dianggap tidak selalu yang bersifat ain atau memiliki wujud yang bisa digenggam dan dikuasai, melainkan segala hal yang memiliki nilai, baik memiliki wujud maupun tidak. $^{14}$

Bitcoin sendiri merupakan sesuatu yang memiliki nilai disebabkan oleh kepercayaan dan kesepakatan para penggunanya, para pengguna bitcoin menganggapnya memiliki nilai, sehingga atas kepercayaan tersebut menjadikan bitcoin memiliki nilai. Apabila suatu saat komunitas atau para pengguna menganggap bitcoin sudah tidak lagi berharga dan tidak memiliki nilai, maka bitcoin sudah bukan lagi termasuk harta. Sederhananya, bitcoin berharga karena orang menghargai bitcoin.

${ }^{13}$ Achmad Wafyuddin Nurillah, Skripsi: Bitcoin Sebagai Alat Transaksi Dan Investasi, (Semarang: Universitas Islam Negeri Walisongo, 2018), hlm. 85

${ }^{14}$ Fathurrahman Djamil, Hukum Ekonomi Islam, (Jakarta : Sinar Grafika, 2013), hlm.173- 174 
Dalam hal ini mubahhitsin merujuk pada kitab Muamalah alMaliyah wa al Muashshiroh karya Syech Muhammad Rawas halaman 23:

"nuqd adalah segala sesuatu yang bisa diambil nilainya oleh manusia dari barang-barang tambang yang di cetak, lembaran-lembaran, atau sejenisnya yang diterbitkan oleh lembaga resmi yang terkait."

Pembayaran zakat menggunakan bitcoin mungkin masih belum banyak orang yang mengetahuinya, karena memang pembayaran zakat dengan metode ini masih sangat sedikit yang menerapkannya. Begitupula keberadaan bitcoin sendiri masih banyak mendatangkan pro-kontra. Jika melihat dari sisi pandangan PWNU Jawa Timur bahwa bitcoin dikategorikan sebagai harta maka berlaku juga zakatnya, karena hal ini didasarkan pada keserupaan bitcoin dengan nuqud yang menyerupai dain. Dalam Kitab Hukum Ekonomi Syariah (KHES) Pasal 678 juga menjelaskan harta-harta yang disimpan dan telah mencapai nisab dan melampaui satu haul maka harta tersebut wajib dikeluarkan zakatmya.

Ketua Komisi Dakwah MUI, KH Cholil Nafis memaparkan bitcoin hukumnya adalah mubah sebagai alat tukar bagi yang berkenan untuk menggunakannya dan mengakuinya. Namun bitcoin sebagi investasi hukumnya adalah haram karena hanya alat spekulasi bukan untuk investasi, hanya alat permainan untung rugi buka bisnis yang menghasilkan. ${ }^{15}$ Akan tetapi, tidak sedikit yang menghimbau untuk menghindari menggunakan bitcoin karena sebagaimana yang telah dijelaskan sebelumnya aspek yang menjadi pertimbangan yaitu bahwa penggunaan bitcoin sendiri terdapat unsur gharar (ketidakjelasan) serta bertransaksi menggunakan bitcoin dekat dengan kemafsadatan (kerusakan) daripada kemaslahatan (manfaat). Dengan demikian maka bitcoin dapat dikatakan haram karena mengandung unsur gharar dan tidak didapat digunakan sebagai pembayaran zakat. Ini diperkuat dengan Fatwa MUI No 13 Tahun 2011 tentang Hukum Zakat atas Harta Haram yang menegakan bahwa harta haram tidak menjadi objek wajib zakat. Zakat wajib ditunaikan dari harta yang halal, baik hartanya maupun cara perolehannya.

Komisi Fatwa MUI mendasarkan keputusan tersebut pada firman Allah SWT dalam QS al-Baqarah [2]:267 yaitu yang berbunyi: 
"Hai orang yang beriman, nafkahkanlah sebagian dari hasil usahamu yang baik-baik dan sebagian dari apa yang Kami keluarkan dari bumi untuk kamu."

Serta HR Muslim :

Harta haram, baik zat maupun cara memperolehnya, merupakan sesuatu yang tidak layak untuk dibelanjakan di jalan Allah. Karena, Allah hanya menerima sesuatu yang baik. "Sesungguhnya Allah itu Mahabaik dan tidak menerima kecuali yang baik."

Keabsahan suatu akadpun harus terhindar dari unsur gharar dan riba. ${ }^{16}$

"Selama dalam akad tidak terdapat unsur kezaliman, gharar (ada unsur ketidakjelasan), dan riba, maka akad tersebut sah." (Syarh Al-Mumthi', 9:120)

Bitcoin akan bekerja dengan fungsi yang sama seperti uang fiat jika diterima sebagai mata uang. Namun, pembayaran tunai dan tunai debit didorong karena uang diterima secara fisik. Penerimaan metode pembayaran ini tergantung pada pusat atau institusi zakat di masingmasing negara. ${ }^{17}$

\section{PENUTUP}

Penerapan hukum untuk kasus bitcoin diumpamakan dengan kasus menjual ikan dalam air, yaitu (1) Al-ashl-nya adalah menjual beli ikan dalam air; (2) Furu'-nya adalah menjual beli uang virtual bitcoin di dunia maya; (3) Hukum ashal-nya adalah haram menjual beli ikan di dalam air; (3) 'illat atau kesamaan sifatnya, yaitu sama-sama membeli sesuatu yang tidak jelas, baik kuantitas maupun kualitas barangnya. Dengan demikian, jual beli bitcoin sama dengan jual beli ikan di dalam air, yakni sama-sama mengandung unsur gharar.

Jika melihat dari sisi pandangan PWNU Jawa Timur bahwa bitcoin dikategorikan sebagai harta maka berlaku juga zakatnya, karena hal ini

https://rumaysho.com/23499-harta-haram-itu-sumbernya-dari-zalim-ribadan-gharar.html (Diakses Tanggal 10-05-2020)

${ }^{17}$ Che Mohd Fakhri Che Ludin, et.al., Bitcoin: Analisis Bitcoin Melalui Muamalat dan Mașlahat, ISES4101 Ijtihad dalam Isu-isu Sains dan Pemikiran Saintifik, (Malaysia: Universiti Malaya, t.th). hlm. 11 
didasarkan pada keserupaan bitcoin dengan nuqud yang serupa dengan dain. Ketua Komisi Dakwah MUI, KH Cholil Nafis memaparkan bitcoin hukumnya adalah mubah sebagai alat tukar bagi yang berkenan untuk menggunakannya dan mengakuinya. Namun bitcoin sebagi investasi hukumnya adalah haram karena hanya alat sepekulasi bukan untuk investasi, hanya alat permainan untung rugi bukan bisnis yang menghasilkan. ${ }^{18}$ Akan tetapi, tidak sedikit yang menghimbau untuk menghindari menggunakan bitcoin karena penggunaan bitcoin sendiri terdapat unsur gharar (ketidakjelasan) serta bertransaksi menggunakan bitcoin dekat dengan kemafsadatan (kerusakan) daripada kemaslahatan (manfaat). Dengan demikian maka bitcoin dapat dikatakan haram karena mengandung unsur gharar dan tidak didapat digunakan sebagai pembayaran zakat. Ini diperkuat dengan Fatwa MUI No 13 Tahun 2011 tentang Hukum Zakat atas Harta Haram yang menegaskan bahwa harta haram tidak menjadi objek wajib zakat. Zakat wajib ditunaikan dari harta yang halal, baik hartanya maupun cara perolehannya. Komisi Fatwa MUI mendasarkan keputusan tersebut pada firman Allah SWT dalam QS Al-Baqarah [2]:267 yaitu yang berbunyi: "Hai orang yang beriman, nafkahkanlah sebagian dari hasil usahamu yang baik-baik dan sebagian dari apa yang Kami keluarkan dari bumi untuk kamu."

\section{DAFTAR PUSTAKA}

Ausop, Asep Zaenal \& Aulia, Elsa Silvia Nur. Teknologi Cryptocurrency Bitcoin Untuk Investasi Dan Transaksi Bisnis Menurut Syariat Islam, Jurnal Sosioteknologi, Vol. 17, No 1, April 2018. DOI: http://dx.doi.org/10.5614\%2Fsostek.itbj.2018.17.1.8

Che Ludin, Che Mohd Fakhri, et.al., Bitcoin: Analisis Bitcoin Melalui Muamalat dan Mașlahat, ISES4101 Ijtihad dalam Isu-isu Sains dan Pemikiran Saintifik. Malaysia: Universiti Malaya, t.th.

Darmawan, Indra. Pengantar Uang dan Perbankan, Jakarta: PT Rineka Cipta, 1992.

Djamil, Fathurrahman. Hukum Ekonomi Islam, Jakarta: Sinar Grafika, 2013.

https://bitcoin.org/id/faq (diakses tanggal 27-03-2019)

18 https://kumparan.com/kumparannews/11-poin-mui-tentang-bitcoin-yangdiharamkan-sebagai-investasi/full ( Diakses Tanggal 10-05-2020) 
40 | Adliya: Jurnal Hukum dan Kemanusiaan, Vol. 14, No. 1, Juni 2020

https://edukasibitcoin.com/mui-malang-haramkan-bitcoin (Diakses 2012-2019)

https://islam.nu.or.id/post/read/86225/hukum-transaksi-denganbitcoin (Diakses tanggal 29-01-2020)

https://kumparan.com/kumparannews/11-poin-mui-tentang-bitcoinyang-diharamkan-sebagai-investasi/full ( Diakses Tanggal 10-052020)

https://www.cnnindonesia.com/teknologi/20180524143721-185300968/masjid-di-inggris-halalkan-bitcoin-untuk-bayar-zakat (Diakses tanggal 18-07-2019)

Ibrahim, R. Maulana, Paper Seminar Internasional Toward a Less Cash Society in Indonesia, Jakarta: Direktorat Akunting dan Sistem Pembayaran Bank Indonesia, 2006.

Lidia, Dara. Eksistensi Bitcoin Dalam Perspektif MaqâSSid Al-Syar'Īyah, Petita, Volume 3, Nomor 2, Januari-Juni. 2018.

Nurhisam, Luqman. Bitcoin Dalam Kacamata Hukum Islam, Vol. 4, No. 1, Juni 2017.

Nurillah, Achmad Wafyuddin. Skripsi: Bitcoin Sebagai Alat Transaksi Dan Investasi, Semarang: Universitas Islam Negeri Walisongo. 2018.

Wijaya, Dimas Ankaa dan Darmawan, Oscar. Blockchain dari Bitcoin untuk Dunia, Jakarta: Jasakom, 2017.

Wijaya, Dimaz A. Mengenal Bitcoin \& Cryptocurrency, Medan: Puspantara. 2016

Wijaya, Sandra. Skripsi: Transaksi Jual Beli Bitcoin Dalam Perspektif Hukum Islam, Universitas Islam Indonesia: Yogyakarta, 2018. 